\title{
Mad-hatting in Samuel Beckett's Waiting for Godot
}

\section{Keren M. Smith}

It is entirely appropriate that readers of Beckett should be prone, from time to time, to the sense of powerlessness that afflicts his characters as they sway tipsily on the edge of silence and inactivity. The armless, legless, talking-head narrator of Beckett's 1953 work, The Unnamable, stuck in a jar and festooned with lights like some bizarre Adams-family Christmas tree, has all the mesmeric quality of a voice repeatedly drawing attention to its own impotence. "I have to speak [...] Having nothing to say [...] there is nothing, nothing to discover, nothing to recover, nothing that can lessen what remains to say ..."1 So by degrees he effaces himself, stripping himself of the accretions of words contaminated by their own contextual history. ${ }^{2}$ An acolyte, cleansed and emptied by repeated gestures of self-abnegation. On his knees, "then crawling on my belly or rolling on the ground" (329). But this same voice also sets up the reader's divestment, as the conceptual and explanatory mechanisms of thinking are dismantled with indifferent yet insistent care. Distinctions between subject and object are laid out like the disconnected parts of a defunct machine: "The thing to avoid [...] is the spirit of system. People with things, people without things, things without people, what does it matter $[\ldots]$ it will not take me long to scatter them [...] to the winds" (294). The philosophical and cultural rubble of a civilisation offers a bleak landscape, and any kind of commentary in response to this

\footnotetext{
1 Samuel Beckett, Molloy, Malone Dies, The Unnamable (London: John Calder, [1959] 1966), 316. (Published in French by Éditions de Minuit as Molloy: 1951; Malone Meurt: 1952; L'Innommable: 1953.)

2 Steven Connor, "Orders of Magnitude," in The Cambridge Companion to Postmodernism (Cambridge: Cambridge University Press, 2004), 70, notes: "In Joyce, words are made to do 'the absolute maximum of work,' said Beckett: 'The more Joyce knew the more he could. He's tending towards omniscience and omnipotence.' Beckett saw his own work as tending to the other extreme, of ignorance and impotence." (Connor is referring to Israel Schenker's interview with Beckett, in the New York Times of 6 May 1956.)
} 
voice crying in the wilderness must appear something of a travesty. The immobile head in the jar is the logical end for such a radical dismembering.

In the same way that Beckett's novels enact a verbal striptease, so his plays incessantly dramatise the problem of having nowhere to go and nothing to do when you get there. Waiting for Godot was published in 1956, three years after The Unnamable. ${ }^{3}$ It inhabits the same uncompromising headspace as the novel, only in this case the space acquires a specific dimension and physicality in the forms of Gogo and Didi. It is perhaps additionally disconcerting that the presence of the actors and objects on stage in no way detracts from the sense of mental vertigo inspired. On the contrary. As Didi says, "There's no lack of void." The play opens with Estragon wrestling with his boot, before abandoning the struggle to utter the first words of the play that anticipate everything, right up until the last words - "Nothing to be done." Vladimir follows suit by removing his hat, examining its empty interior and then coming to the same conclusion: "Nothing to be done," and moreover, "nothing to show," as if he had expected some clue to their next move in these objects that cover the body's extremities; hats, shoes, that once removed from head and feet become receptacles of empty space. Through a piece of theatrical sleight-of-hand material objects are made to deny their own physicality. And if objects seem divorced from their usual function, so gestures contradict words and cancel each other out. The close of acts 1 and 2 echo each other in eerie symmetry:

Estragon: Well, shall we go?

Vladimir: Yes, let's go.

\section{They do not move.}

CURTAIN

[...]

Estragon: Well, shall we go?

Vladimir: Yes, let's go.

3 Waiting for Godot (London: Faber and Faber, 1956). Note, however, that Waiting for Godot was written in the same period as the trilogy, that is during 1948 and 1949, and published by Éditions de Minuit in 1952, the same year as Malone Meurt. 
They do not move. CURTAIN

The only difference between the two acts is that Vladimir and Estragon have changed places. But the place hasn't changed.

This is where Beckett can initially appear difficult of access. Through a rigorous determination to avoid all platitude, all the clutter of what has been said and thought before about existing and thinking and relating, and by attempting to reveal these things in their strange banality, his work appears at times unapproachable. His practised self-effacement is intimidating. How can we follow, engage? The author-figure risks becoming for us like the incomprehensible master in The Unnamable to whom his characters must answer without knowing what he wants or who he is. Their constant undoing and unsaying as they anxiously cover the tracks they never finish making mirrors critical insecurities: insecurity being provided for, as it were, in all of Beckett's works, including the unpublished Eleuthéria whose gaze is already fixed on the dissolving horizon of later writing:

Being as little as possible. Not moving, not thinking, not dreaming, not speaking, not listening, not seeing, not knowing, not wanting, not being able, and so it goes on. ${ }^{4}$

But whether intellectually overwhelming or suicidally perverse, Beckett paralyses in order to shake the kaleidoscope of how we see things. If we become transfixed by what he takes away, we miss out on what he gives. For there is in Beckett an irrepressible energy; a recklessness of spirit and of humour that turns his "steadie aiming at a tombe" into a series of defiant acrobat's tricks. A triumphant circus of words. Waiting for Godot, with its two mad Laurel and Hardy figures (Gogo and Didi in the original Blin

${ }^{4}$ Eleuthéria (ca 1947), a 133-page unpublished typescript, Éditions de Minuit archives, p. 116, cited in Nicholas Zurbrugg, Beckett and Proust (Totowa: Barnes and Noble Books; Gerrards Cross: Colin Smythe, 1988), 46. The original passage reads: "En étant le moins possible. En ne pas bougeant, ne pas pensant, ne pas rêvant, ne pas parlant, ne pas écoutant, ne pas percevant, ne pas sachant, ne pas voulant, ne pas pouvant, et ainsi de suite." (Translation mine). 
production were played by cabaret actors) is, for me, Beckettian theatre at its most generous. In my examination of this early play I wish to highlight the generosity as well as the undermining in Beckett; the manic creativity that projects onto the stage intermittent dazzles of light and movement. In this regard I am both mirroring and refusing the complicitous anxiety that is the hallmark, according to Miller, of contemporary Beckett criticism. ${ }^{5}$

Waiting for Godot was written in French between 1948 and 1949. Despite initial difficulties finding a publisher it was eventually accepted by Éditions de Minuit (1952) and later, after translation into English by Beckett, by Grove Press in New York and Faber and Faber in London. ${ }^{6}$ The first performance of the play, directed by Jean-Marie Serreau, mise en scène Roger Blin, at the Théâtre de Babylone in Paris (3 January 1953) provoked guarded praise from some critics. Amongst the younger members of the audience, however, it appears to have been an unqualified success. Beckett was delighted. "I must, after all, be less dead than I thought." So, too, his play, we assume, must be more than an exploration of the extent to which Beckett, as he once phrased it, "has nothing to say."8

The tinkering about with the word "nothing" at the opening of Waiting for Godot, and the structured purposelessness at the close of each of its two acts, certainly suggests Beckett has achieved what the Mad Hatter declared impossible; namely, taking less

5 Lawrence Miller, Samuel Beckett: The Expressive Dilemma (Basingstoke: Macmillan; New York: St. Martin's Press, 1992), 2: "It was long customary to preface readings of Beckett's works with the rhetorical concession that no single approach could be adequate. In this way its disturbing and ironic potential could still be preserved. [...] contemporary criticism aims more at a complicity with writers and texts than an accomplished mastery of a literary canon."

${ }^{6}$ Note that the first British edition of the play was censored. Subsequent editions print the full original text. The edition used in this essay is by Faber and Faber, 1965.

7 As quoted in Murray Schumach, "Why They Wait for Godot," The New York Times Magazine, 21 September 1958.

8 See Dirk van Hulle, "Nichtsnichtsundnichts': Beckett's and Joyce's Transtextual Undoings," in Beckett, Joyce and the Art of the Negative, ed. Colleen Jaurretche (Amsterdam and New York: Rodopi, 2005), 59: "Later, Beckett described himself as "a young man with the itch to make and nothing to say."' 
rather than more than nothing. Equally clear, is that much of the word-play in the drama revolves around a series of questions and contradictions whose effect is not to qualify what is being said, or to render it more ambiguous, so much as to erase it altogether and thus establish the pattern of verbal sabotage, or, "lessness" - "first deface, then erase" — that characterises later works. From remarks about the physical presence of the characters:

Vladimir: So there you are again.

Estragon: Am I? (9)

to their sense of time and place:

Estragon: In my opinion we were here.

Vladimir: (looking around). You recognise the place?

Estragon: I didn't say that.

to the building up and cutting down of any sense of pathos, or the audience's bemused expectation that the play may (perhaps) be about to open onto a plane of transcendent meaningfulness:

Vladimir: Let us not waste our time in idle discourse! (Pause. Vehemently.) Let us do something, while we have the chance! It is not every day that we are needed. Not indeed that we personally are needed. [...] The tiger bounds to the help of his congeners without the least reflection, or else he slinks away into the depths of the thickets. But that is not the question. What are we doing here, that is the question. And we are blessed in this, that we happen to know the answer. Yes, in this immense confusion one thing alone is clear. We are waiting for Godot to come-

Estragon: Ah!

Pozzo: Help!

Vladimir: Or for night to fall. (Pause.) We have kept our appointment, and that's an end to that. We are not saints, but we have kept our appointment. (79-80)

\footnotetext{
9 The official translation of "salir, ensuite, nettoyer" is "first dirty, then make clean", The Unnamable, 302.
} 
Clearly, to be or not to be is not the question here in this fine passage of grandiloquent blathering where each phrase makes a nonsense of the preceding one. In a manner which ensures the audience shares some of the tormenting diversions that animate, and arrest the characters on stage, contradictions in rhetoric and action perversely crank up the engine of the drama and then throw in the spanner that cuts off the sound.

Ultimately, however, the play's use of contradiction is more complex than this, just as the flavour of Beckett's world is too ambiguous to equate with nihilism. The whole point of the logic of contradiction is that it involves neither a yes nor a no but both at the same time, resulting in a logical dead-end that can only be resolved through a form of paradox. Except that in Beckett there is no sense of the settled ambiguity that defines conventional paradox and makes it habitable. A contradiction remains a contradiction. A wasteland of logic. In this way his play captures the mood of deliberately sustained uncertainty that has characterised much modern and post-modern writing, while harking back to the reasoning of more ancient sceptics. Waiting for Godot could, in fact, be described as the fleshing out in theatrical terms of the sceptic's argument, whereby consideration of the pro and contra leads to epoche, or, the suspension of judgement. This deliberate embrace of contrary possibilities is emphasised early on in the play's reference to the story of the two thieves on the cross, a story in which two lives are literally held in the balance between life and death, heaven and hell. As Vladimir reminds us, "One is supposed to have been saved and the other ... (he searches for the contrary of saved) ... damned" (12). The element of uncertainty in the story is intensified by the different accounts of it in the four Gospels where only one of the four represents the possibility of a thief being saved. Luke's account succeeds in creating what Chesterton once so neatly described as "an uncertainty continually shaken by a tormenting suggestion." 10 Beckett refers to the story in a 1961 interview conducted by Tom Driver, where he also makes an equation between contradiction and uncertainty as opposed to contradiction and the absence of meaning:

\footnotetext{
10 "The philosophy of Browning," in The Essential G. K. Chesterton, ed. P. J. Kavanagh (New York: Oxford University Press, 1987), 54.
} 
If life and death did not both present themselves there would be no inscrutability. If there were only darkness, all would be clear. It is because there is not only darkness but also light that our situation becomes inexplicable. Take St Augustine's theology of grace, whether it is granted or refused, for example: have you considered the dramatic shape of that theology? Two thieves are crucified with Christ; one is saved, the other is damned. What are we to make of such a fate? ${ }^{11}$

Surely more rather than less in all this metaphorical extremity? What Gogo and Didi, at least, make of "such a fate" is precisely to wait. For waiting, which accounts for the "dramatic shape" of Beckett's play, represents that in-between stage of thought and action whereby definitive movement in one direction or another is deferred until such time as something occurs or someone arrives. The movement which accompanies this sic et non thinking is one of permanent oscillation between rising, sitting, going, staying, balancing everlastingly on the spot because no decision is made. The absent Godot defines the shadowy parameters of this waiting game, spun out over the duration of two acts and accompanied by the construction of temporary "fillers":

Vladimir: What do we do now?

Estragon: Wait.

Vladimir: Yes, but while waiting. (17)

While waiting, for Godot to come, or night to fall, Gogo and Didi must somehow fill in their time. Nothing too elaborate. They might miss Godot. So they practise little courtesies ("Pozzo: And thank you / Vladimir: Thank you. / Pozzo: Not at all. / Estragon: Yes yes / Pozzo: No no. / Vladimir: Yes yes / Estragon: No no" [47]) and acts of charity, towards Lucky, for instance, who kicks them, or Pozzo. They experiment with their moods, sob, laugh, and go to the theatre, like us, watching the spectacle of their fellows. They stand still, run about, and do their exercises. They fall silent. They talk. Above all, they talk. Chatting about things

11 Tom F. Driver, "Beckett by the Madeleine," Columbia University Forum 4, no. 3 (Summer 1961): 23. 
metaphysical, about the possibility and practical aspects of suicide. They tell jokes, ask each other questions, abuse each other:

Vladimir: Ceremonious ape!

Estragon: Punctilious pig!

$[\ldots]$

Vladimir: Moron! (75)

Anything to keep up some kind of momentum, they tread water, verbally speaking, to stave off drowning. For silence is feared as much as sleep, solitude and death, which is why contradiction is used more as a strategy of postponement than of negation; a means of piling up words in endless tricks of construction so as to articulate empty space.

\section{Long silence.}

Vladimir: Say something!

Estragon: I'm trying. Long silence.

Vladimir: (in anguish). Say anything at all!

Estragon: What do we do now?

Vladimir: Wait for Godot. (63)

According to the classic sceptic argument, weighing up contradictory evidence leads first to the suspension of judgement and then to ataraxia, or, that mood of stillness and tranquillity that accompanies the acceptance of being unable to decide. Indecision for the pyrrhonist meant not to trouble oneself. But Gogo and Didi do trouble themselves. And they are as afraid of stillness as they are of silence. Thus where the last novel of Beckett's trilogy approaches the sceptic's mood of stillness as the narrator attempts to unburden himself of the weight of his humanity, ${ }^{12}$ Gogo and Didi continually "resume the struggle." Lucky keeps a hold on his cases. The stage directions at the opening of act 2, where Vladimir

\footnotetext{
12 Note, also, the progressive shedding of limbs and identities from the early novels through to later plays such as Oh les beaux jours (1963), where the characters are buried up to their waist, then their neck, until finally in Le Souffle the stage lighting builds and fades to the sound of an exhaling breath.
} 
sings a little song to himself, reproduce in movement the mood of pained yet determined indecision conveyed in the play as a whole. Vladimir enters "agitatedly." He stops still and looks at the tree, then "begins to move feverishly about the stage." Coming, going, stopping, as though the stage itself were in a permanent see-saw of movement, he at last begins to sing. Loudly. Not altogether tunefully. Towards the end of the song he halts and broods, as if relaxing slowly into apathy. After remaining "silent and motionless" for a time he again "begins to move feverishly about the stage," animated and truculent in spite of himself. Fighting for a life he doesn't know what to do with. Stillness and silence are too like the stasis of death which is as much feared and longed for as the arrival of Godot. Confronted by the possibility of the latter's imminent arrival, Gogo and Didi are, at first, joyful; then terrified:

Vladimir: (triumphantly). It's Godot! At last! Gogo! It's Godot! We're saved! Let's go and meet him! (73)

They rush about, lose each other, hide behind the tree (which provides five leaves' cover by act 2), and then subside with relief. Certainty, whether as presence or absence, is more unbearable than uncertainty. It is the foundation of what Dostoyevksy's underground man called the "brick wall of facts" that deprives the players of the illusion of their chaotic freedom. Hence it is always too late, too difficult to commit suicide; too risky to abandon the watch for Godot: "Don't let's do anything. It's safer" (18). So Gogo and Didi remain in limbo, that mythical place that is neither heaven nor hell, nor yet a place of rest. Fearing the light, running from the darkness, they maintain their agitated running on the spot.

The frustrated boredom of Vladimir and Estragon's waiting and the descending-lift feeling that accompanies vicarious reflection about the purpose of habitual daily activities is likely to have as depressing an effect on the audience as a double-gin on an empty stomach: heady exhilaration swiftly followed by a sensation of pumped-out emptiness. Yet Beckett expressly calls this play a tragicomedy. Where, then, does the comedy come in?

Mélèse defends Beckett from easy accusations of pessimism by referring to the camaraderie between the characters and the "love of humanity" that informs the works: 
[I]f Beckett is a pessimist, he is not without pity. He feels a brotherly sympathy for his marginalised (disgraciés) characters and laments the fact that they are repeatedly the playthings of illusion and existential anguish. [...] The clumsy affection between Vladimir and Estragon, the tenderness between the old couple in the rubbish-heap, Winnie and Willie - can this love of humanity, discreetly veiled by a mask of humour and irony, be the mark of a totally defeatist attitude, of an irremediable pessimism? ${ }^{13}$

That the so-called "fire of love" in Beckett should really enable man to live the "implacable tragedy" of his life is possibly to take the "clumsy affection" between Gogo and Didi to greater lengths than the script allows. Especially in view of the fact that Gogo and Didi come several times to the conclusion that they would be better off on their own, if only they could make up their minds to actually leave each other. It is true, the fact that they are playing the waiting-game together has its little comforts. Their chit-chat is buoyed up by mutual promptings and encouragements, one covering the other with his coat as he sleeps and soothing him when he wakes from a nightmare. Ultimately, it seems they prefer the solace of another presence to solitude, after the manner of Camus' Salamano and his dog, who have grown accustomed to each other's sores and snarls. Suicide is rejected, in part, because of the risk that one of them might be left alone ("Don't touch me! Don't question me! Don't speak to me! Stay with me!") (58)

From passion for humanity to a complete absence of passion, Robbe-Grillet's classic reading of the play's emotional impact goes almost to the opposite extreme to Mélèse, evoking a degree zero of meaning and pathos:

As for Gogo and Didi [...] their situation can be summed up in this simple statement, which it seems impossible to take any further: they are there, they are on the stage [...] the plot can be summed up in three words - "On attend Godot" (We're waiting for Godot) which is repeated incessantly like a refrain. But it's a pointless, monotonous refrain, because the waiting is of no interest to anybody

${ }^{13}$ Pierre Mélèse, Samuel Beckett: Textes de Beckett, points de vue critiques, témoignages, chronologie, repertoire des oeuvres, bibliographie, illustrations (Paris: Seghers, 1966), 128-29. (Translation mine) 
[...] It's not a matter of hope, or anguish, or even despair. It's just an alibi. ${ }^{14}$

Robbe-Grillet is, in effect, using Beckett's drama to illustrate his own arguments about the inappropriateness of tragic vision to contemporary literature, although some of his points correspond to comments Beckett himself was to make in the 1961 interview. Robbe-Grillet's basic tenet is that tragic pathos is inextricably bound up with a metaphysics, or with an overarching scheme of value and purpose which determines that we react to adversity with nostalgia for a happier, more meaningful state of affairs. This, Robbe-Grillet believes, makes it harder for us to wrest from adversity new meaning, to see it as an opportunity to reconfigure our world. We grow resigned to the failure of hopes and beliefs we have, in effect, only constructed for ourselves. Tragedy for RobbeGrillet is not a conceptual and aesthetic framework corresponding to a human reality; it is a framework that helps create the reality it purports to represent. In his determination to sever the link between emotion and such preconceived value (an enterprise Beckett would surely have sympathised with given his own dislike of systems and ideologies), Robbe-Grillet depicts an emotional landscape that is completely flat and empty, with no dimension beyond that of the physical presence of the characters on stage.

This reading of the play's generic ambivalence works up to a point. The most basic facts of Vladimir and Estragon's physical presence on stage are frequently underscored: they feel the cold; they get tired; they are hungry; they relieve themselves; they fart and have smelly breath and feet. They try not to "neglect the little things of life" by keeping their flies buttoned up; their boots on, or off when their feet hurt. They keep themselves together, materially speaking, without the benefit of elevating words or gestures. But Robbe-Grillet's reading overlooks the fact that the characters' physical presence still poses a problem, and not just for the "bargain-hunters" after easy meaningfulness in the audience. It poses a problem for Gogo and Didi. As we have seen. They are not resigned to their waiting any more than they are confined to their

\footnotetext{
14 Alain Robbe-Grillet, Pour un nouveau roman (Paris: Minuit, 1963), 98, 100. (Translation mine)
} 
bodily functions. They also, to their continuing discomfort, have a mind, an imagination - the real seat of tragedy in twentieth-century literature. ${ }^{15}$ Consciousness is a problem until they lose it, in sleep or in death. The imagination is linked to nerves and passions, and will go on being stirred, unexpectedly, even in the character of Lucky. Lucky, who appears to be "asleep on his feet," and who is denied, apparently, even the freedom of waiting as he mindlessly takes orders from another, is still very much alive. Like the sudden explosion of sparks from the cinders of a dying fire when poked with a stick, Lucky, when prodded by his master-“"Think, pig!" (42) - bursts into visionary gibberish. We should be warned. The character of Lucky arguably encapsulates the contained energy of the play as a whole, for all its deadpan humour:

For the moment he is inert. But he might run amuck at any minute. (79)

Beckett himself chooses terms like "confusion" and "mess" to account for the shape and impact of his plays which in fact embrace tragic and comic elements without really subscribing to either category. He thus acknowledges the reality of pain which Robbe-Grillet tends to trivialise in his essay on tragedy as merely the product of a flaw in thinking. On the other hand tragedy, for Beckett, as for Robbe-Grillet, is linked to a distinct moral vision whereby the characters may be both enlightened and judged by their fate. This sense of the tragic is rejected. Beckett illustrates the point with reference to Racine's Phèdre in the same passage where he speaks of the double, and therefore uncertain, fate of the thieves on the cross in the Gospels:

The destiny of Phèdre is sealed from the beginning: she will follow her path into the darkness. Gradually, she will even gain some

\footnotetext{
15 But hardly unique to our age. The sixteenth-century sceptic Montaigne has written some superb passages on the power of the imagination in his essays: "When imaginary thoughts trouble us we break into sweats, start trembling, grow pale or flush crimson; we lie struck supine on our feather-beds and feel our bodies agitated by such emotions; some even die from them." (The Essays of Michel de Montaigne, trans. and ed. M. A. Screech [Harmondsworth: The Penguin Press, 1991], 110.)
} 
enlightenment. At the beginning of the play she is partially enlightened, by the end she is totally enlightened even though there is no doubt that she herself is moving towards darkness. [...] In this scheme of things illumination is possible. The question wouldn't arise either if we believed the opposite to be true, that salvation was assured. But wherever we have both darkness and light, we also have incomprehensibility. The key word in my plays is "Perhaps."

Tragedy therefore is assumed to operate according to a logic of definite ends and beginnings, a purposive teleology. Beckett's tragicomedy, by comparison, keeps both beginning and ending disconcertingly open, yet static, undecided between alternative uncertainties.

The same suspension of judgement that informs the play's contradictory logic could be said to qualify the nature of the emotional responses it represents and potentially evokes in an audience. In Diderot's celebrated eighteenth-century novel, Jacques le fataliste, his main character saw as one of the weaknesses of human beings their inability to know when to laugh and when to cry. Beckett's characters are confused even about the nature of their confusion. As Vladimir asks the boy sent from Godot:

Vladimir: You're not unhappy? (The Boy hesitates.) Do you hear me?

Boy: $\quad$ Yes, sir.

Vladimir: Well?

Boy: I don't know, sir.

Vladimir: You don't know if you're unhappy or not?

Boy: $\quad$ No, sir.

Vladimir: You're as bad as myself. [...] (51)

Not knowing whether to be happy or unhappy does not equate with not feeling anything, and an emotional seesaw rather than a mechanical exchange is the result. This much is clear from stage directions: "Vladimir: (gloomily.) It's too much for one man. (Pause. Cheerfully.) On the other hand what's the good of losing

${ }^{16}$ Driver (n. 11 above): 23. 
heart now, that's what I say" (10). "Vladimir: [...] (Joyous.) There you are again [...] (Indifferent.) There we are again [...] (Gloomy.) There I am again" (59); and from the nature of the dialogue, which juxtaposes distress with chatty banality, or simply undercuts the former by turning it into a melodramatic pose whose emotional flavour is both ludicrously silly and savage. The spectacle of Lucky, for instance, his neck rubbed raw by the rope around it, arouses fear and pity in both the characters and, hypothetically, the audience. But Gogo and Didi's sympathy is soon diverted by an interest in Lucky's chicken bones and their competition with one another for charity points as they attempt to respond to Lucky's dilemma: "Vladimir: (exploding). It's a scandal! [...] Estragon: (not to be outdone). A disgrace!" (27). Estragon then resumes his gnawing on the chicken bone just as anyone might resume eating after watching the spectacle of human misery on the television. Or at the theatre. ${ }^{17}$ Estragon and Vladimir's distress over Lucky is further undermined when, after rushing over to wipe the tears from Lucky's eyes with a handkerchief, Estragon is kicked viciously on the ankle by Lucky, the object of his fear and pity. Shifting sympathies between characters at this juncture is exacerbated by their own individual confusion which means that no-one is able to hold a tragic line for long. Pozzo starts "groaning" and "clutching his head," diverting sympathy away from the maltreated Lucky towards himself. Vladimir and Estragon become the enthralled audience at a more polished tragedy performance than Lucky was capable of:

Vladimir: He can't bear it.

Estragon: Any longer.

Vladimir: He's going mad.

Estragon: It's terrible.

Vladimir: (to Lucky). How dare you! It's abominable! Such a good master! Crucify him like that! After so many years! Really! (34)

\footnotetext{
${ }^{17}$ Note the meat pies on sale during the interval of a 1999 Wellington production of Sweeney Todd, which provided an invitation to morbid relish of violence rather than the vaguely gourmandising indifference of Estragon.
} 
At this point Pozzo starts sobbing. Then, after more bandying about, he suddenly pulls himself up, denies everything he has just said, and starts rummaging calmly for his pipe.

The characteristic flickering and fading of feeling strains even Beckett's own idea of an oscillation between light and dark, since the terms "light," "dark," "hope," "despair," are themselves toyed with and disarranged. The feelings that animate the characters are apparently dislodged from what might be construed as appropriate thoughts or reactions, disinherited from a meaningful universe. Nevertheless, if nerve-endings have difficulty interpreting the confused signals from the brain they still go on twitching. At odd intervals. Pozzo, for example, is effusively earnest when there is nothing to be earnest about, or injects a range of feeling into a fine ode about the twilight while being unaware of, or indifferent to, Lucky's degradation. It is as though the characters' reservoir of feeling has broken down the walls of the usual channels, and got out of hand, just as their words and gestures are frequently cut adrift from any appropriate context. The most extreme example of the disjunction between words and meaning, feeling and context, is Lucky's outburst in the latter part of act 1 where a surreal découpage of words from different social contexts and registers comes pouring out of Lucky's mouth in a seemingly undifferentiated yet prophetic-sounding stream. Not the most studied of deadpan interpretations of Waiting for Godot can overlook the passion of this moment. The agitation of the surrounding characters, like the gyrations of Lucky himself, are clearly written into the stage directions. This is the sound-version of Munch's scream, the verbal equivalent of Petrushka's frenzied dancing about the stage, and if at times the other characters also appear like puppets loosed from the guiding string of learned gestures and words, Lucky is the puppet who cannot work free from the rope about his neck, and for whom words can no longer mean but only register pain. He "struggles and shouts his text" like one bleeding to death.

Yet it is at this very pitch of distress and confusion, where words seem reduced to pure noise, that Waiting for Godot, for me, triumphs both as theatre, and as art that affirms even while it denies. For what drives the script, at this and other moments, is a powerful energy that engages and wrestles with the words whose 
meaning it has so shaken, hurling them about with the risky precision of a juggling act. Such energy is the essence of the kind of passion necessary to maintaining theatrical momentum, and to imprinting on the retina of the audience's imagination the poetry of the dialogue. It is what gives much of the nihilistic tomfoolery between Gogo and Didi, the "blathering about nothing in particular" (66), a certain reckless generosity. Poised above the void of space they perform break-neck acrobat's tricks on their way down into the pit. Their perplexity about Godot, for example, and the waiting, they transform into a verbal game, where each seems to improvise in turn around the keynotes of the word play:

Estragon: What exactly did we ask him for?

Vladimir: Were you not there?

Estragon: I can't have been listening.

Vladimir: Oh ... nothing very definite.

Estragon: A kind of prayer.

Vladimir: Precisely.

Estragon: A vague supplication.

Vladimir: Exactly.

Estragon: And what did he reply?

Vladimir: That he'd see.

Estragon: That he couldn't promise anything.

Vladimir: That he'd have to think it over.

Estragon: In the quiet of his home.

Vladimir: Consult his family.

Estragon: His friends.

Vladimir: His agents.

Estragon: His correspondents.

Vladimir: His books.

Estragon: His bank account.

Vladimir: Before taking a decision. (18)

The repetition here in different forms of what each one is saying recalls, in manic form, the antics of Thomson and Thompson with their matching moustaches and bowler hats. Beckett, too, has his hat-tricks. All four of his characters wear bowlers which they take off, put on, swap and maltreat, synchronising visual images with 
the beat of the words. Lucky must wear his thinking-hat before he can speak:

Estragon: Wait!

Vladimir: Wait!

Pozzo: Wait!

All three take off their hats simultaneously, press their hands to their foreheads, concentrate.

Estragon: (triumphantly). Ah!

Vladimir: He has it.

Pozzo (impatient). Well?

Estragon: Why doesn't he put down his bags?

Vladimir: Rubbish!

Pozzo: $\quad$ Are you sure?

Vladimir: Damn it. Haven't you already told us!

Pozzo: I've already told you?

Estragon: He's already told us?

Vladimir: Anyway he has put them down.

Estragon: (glance at Lucky). So he has. And what of it? [...]

Estragon: And why has he put them down?

Pozzo: Answer us that.

Vladimir: In order to dance.

Estragon: True!

Pozzo: True!

Silence. They put on their hats.

Estragon: Nothing happens, nobody comes, nobody goes, it's awful.

Vladimir: (to Pozzo). Tell him to think.

Pozzo: Give him his hat.

Vladimir: His hat?

Pozzo: He can't think without his hat.

Vladimir: (to Estragon). Give him his hat.

Estragon: Me! After what he did to me! Never! (41)

To the accompaniment of this mad-hatting, Gogo and Didi run in and out, on and off the stage, colliding and parting like clowns, more like circus clowns, though, than Thomson and Thompson, since, as in the very best of circus traditions, they tumble in and out of insecure laughter. One false grimace would send them over the 
edge. At the same time these clowning movements and gestures help make Waiting for Godot with its subversive logic more than just a theatre of the mind, or a purely verbal drama, even though it is the words in the play that trigger the movement, rather than the other way around. For the passion of Beckettian theatre is not a blind primordial force so much as a poetic energy that creates a rhythm strong enough to demand bodily movement - as well as stillness and silence. The rhythmic drive of the dialogue in Waiting for Godot is itself movement; is already theatre. In this sense, the script has some of the attributes of rap. Rap, with its pronounced beat and rhythmic recitation of words, exploits a special style of verbal repartee. For these reasons, a rap version of Waiting for Godot, which fully exploits the play's verbal energy, would offer some interesting, if unorthodox, possibilities for theatrical representation.

This, of course, goes right against the intentions of the author which have been stated with particular, Pozzo-like authoritarianism despite the usual claim that Beckett, "[b]y refusing to explain himself, [has] allowed others greater freedom in explaining him [...]". ${ }^{18}$ Productions of Waiting for Godot are bound by a number of authorial strictures, including the forbidding of women players, and the general insistence on respect for the original version approved by Beckett. Televised versions are authorised on the sole and unique condition that they respect Beckett's rules of direction as captured in the American and French productions directed by Walter Asmus. An energetic son-et-lumière-type staging of the play is a far remove from the intellectual sepia of these productions. But isn't it time for the reader/spectator to test the limits of interpretative canonisation a little? Is Lucky to be eternally earth-bound by bedraggled flaxen locks? The fidelity to the original costumes seems particularly unnecessary as these were Roger Blin's, not Beckett's idea in the first place, and, contrary to the original "Lucky's" view, bowler hats are no longer timeless elements in the average man's wardrobe. ${ }^{19}$

\footnotetext{
${ }^{18}$ Miller (n. 5 above), 7.

19 A comment from Jean Martin, who played Lucky in the original Blin/Beckett production. (“En créant Godot," Magazine Littéraire 372 (Janvier 1999), 54.
} 
If I don't feel quite convinced by some of Philippe Adrien's decisions for a 1993 production, I sympathise with the desire to let the play slip the leash of comfortable modern and post-modern angst about presence and meaning:

In some commentaries, it is said that Beckett can be neither incarnated nor psychologised. But such remarks come from directors who have imitated the Beckettian form of which Beckett himself was a prisoner. Beckett gave the litterati the feeling that he had reached a limit from which there was no turning back, a kind of tabula rasa. [...] But Beckett did not abolish narrative. ${ }^{20}$

One of Adrien's theatrical outworkings of his views about dramatic incarnation and the post-atomic flavour of Beckett's text, is to identify a fart that escapes the characters ("Who farted?") with the little cloud to which Vladimir draws attention ("Look at that little cloud"). This then becomes the yellowish smoke of an atomic bomb, an event which Adrien suggests we are collectively, and spuriously, at pains to forget: "I took this as a reference to the bomb. So this fart was the atomic bomb." While Beckett would have no doubt been amongst the first to enjoy the spectacle of an atomic fart, this seems to take concretisation, and political awareness, to noisome extremes.

But however we respond to what Beckett offers in this play, we cannot go away from a performance, or even a private reading, with nothing. According to Tim Parks, with Beckett "it is the persistence of a 'religious' seriousness in the declared absence of any sustaining metaphysics that gives his work its special, for some, saintly, pathos." ${ }^{21}$ We may add that Waiting for Godot lights

20 Philippe Adrien, "Un écrivain post-atomique", Magazine Littéraire 372 (Janvier 1999): 46. ("Dans certaines remarques on lit que Beckett ne peut pas être incarné ou psychologisé. Mais cela vient de metteurs en scène qui ont imité cette forme beckettienne, dont lui-même, Beckett, s'est trouvé prisonnier. Beckett a donné le sentiment aux littérateurs qu'il touchait à une limite sur laquelle on ne pourrait jamais revenir, une sorte de table rase. [...] Mais Beckett n'a pas aboli le récit." [Translation mine])

21 Tim Parks, "Beckett: Still Stirring," The New York Review of Books, 13 July 2006. 
up the dark of the void into which it constantly threatens to fall with a fireworks display of energy and wit that, in the end, is more defiant than self-deprecating. 